\title{
FRONTIERS capacity building: An overview
}

James R. Foreit

Population Council

Follow this and additional works at: https://knowledgecommons.popcouncil.org/departments_sbsr-rh

Part of the Demography, Population, and Ecology Commons, Family, Life Course, and Society Commons, and the Women's Health Commons

How does access to this work benefit you? Let us know!

\section{Recommended Citation}

Foreit, James R. 2002. "FRONTIERS capacity building: An overview," FRONTIERS Report. Washington, DC: Population Council. 


\section{Population Council}

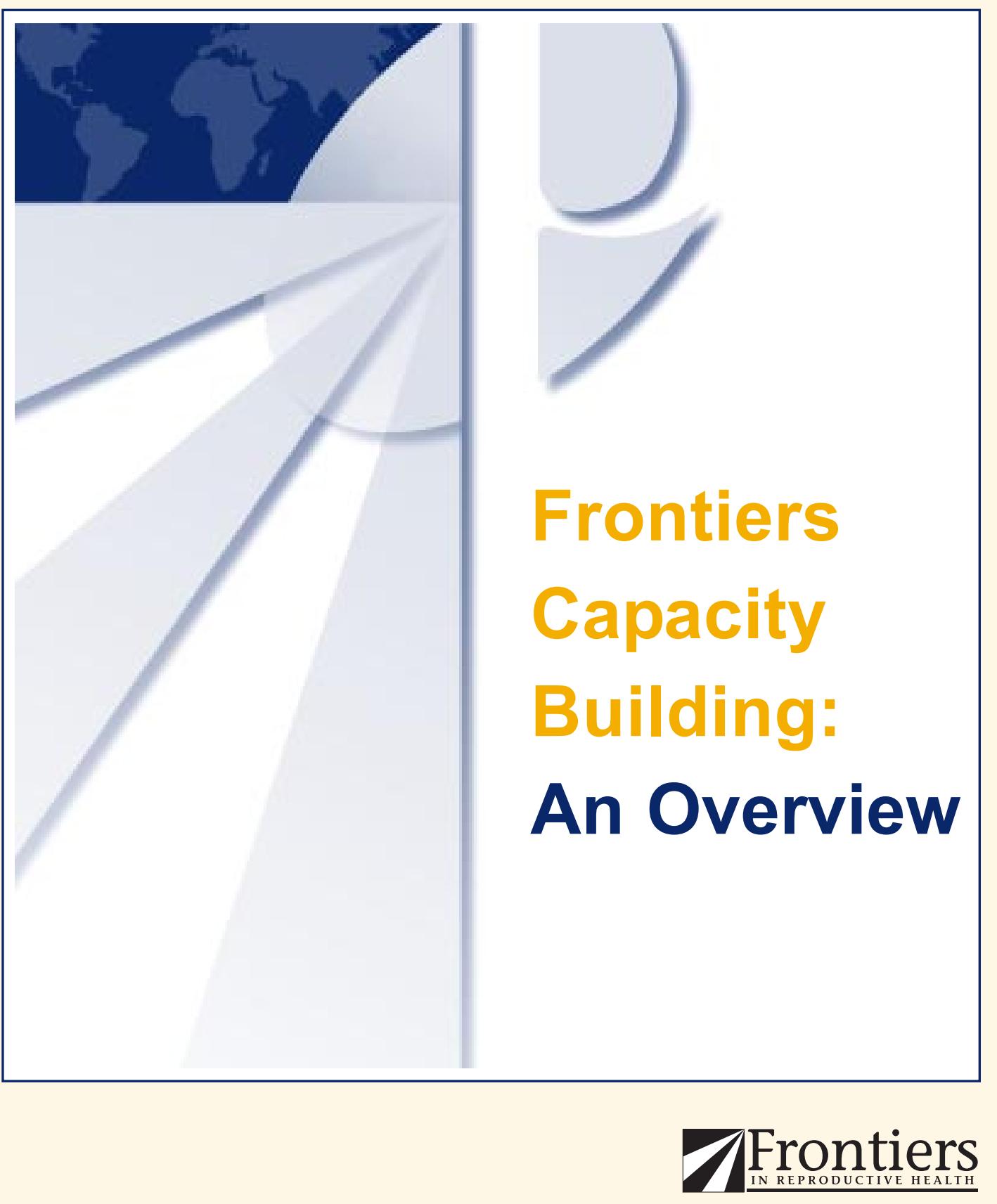


12 Population Council

7 Frontiers

\section{FRONTIERS CAPACITY BUILDING: AN OVERVIEW}

James R. Foreit

March 2002 


\section{FRONTIERS Capacity Building: An Overview}

The Frontiers in Reproductive Health Program (FRONTIERS) builds on more than 20 years of research to improve family planning service delivery programs. A major goal of FRONTIERS is to transfer skills in operations research (OR) so that public and private agencies in developing countries can conduct OR and apply research findings to reproductive health programs and policies.

OR addresses problems in operational effectiveness, access, quality, and efficiency by investigating facets of programs that managers can control and change. The Bureau for Global Health (BGH) of the U.S. Agency for International Development (USAID) has been the major supporter of OR studies since the early 1980s. USAID/BGH has made extensive use of OR findings to help program managers and policymakers make evidencebased decisions on reproductive health, HIV/AIDS, maternal and child health, and primary health care. Other international donors have recently begun to support the use of OR as a problem-solving tool.

FRONTIERS' capacity-building strategy is designed to institutionalize OR by: (1) increasing the consumer base, or the number of organizations that use and support OR; and (2) increasing the number of organizations and individuals capable of conducting and teaching OR. The strategy works through three components:

1. Incorporating OR in the curricula of developing-country training and research organizations;

2. Providing technical assistance to donors and service delivery agencies wishing to increase the use of OR; and

3. Supporting fellowships for developing-country nationals who want to learn OR skills.

Investment in capacity building will ensure that operations research will make a continuing, significant contribution to reproductive health and family planning programs and policies. 


\section{Ensuring the Sustainability of OR}

Ensuring that OR concepts and methodologies are taught in training and teaching agencies in developing countries is crucial to the sustainability of OR. In order for reproductive health agencies to conduct OR and apply its findings as a routine part of their work, the agencies must have knowledgeable staff members with adequate training in OR.

The Frontiers in Reproductive Health Program (FRONTIERS) of the Population Council is a cooperative agreement with USAID to improve family planning and reproductive health service delivery through operations research. The partners in FRONTIERS are Family Health International and the Tulane University School of Public Health and Tropical Medicine.

FRONTIERS provides partner teaching institutions with financial and technical assistance to help launch an OR training program, and subsequently works with them to institutionalize the program within the existing course structure.

FRONTIERS OR courses prepare managers and researchers to work as a team to design and conduct OR studies. The courses emphasize

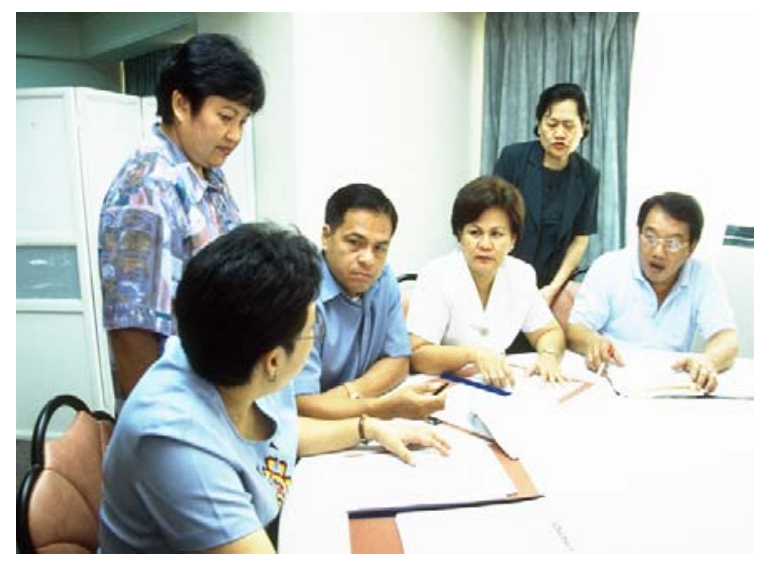
intervention research, proposal writing, and communication of findings. Whenever possible, FRONTIERS provides small grants to support implementation of projects developed during the courses. In addition, FRONTIERS partner Family Health International teaches courses on the economic evaluation of reproductive health programs.

FRONTIERS works with institutions that have a stable funding base, attract students regionally, and have strong faculties with experience in applied research. At present, FRONTIERS works with five collaborating centers:

- Cairo Demographic Center (CDC) in Egypt;

- Makerere University in Kampala, Uganda;

- Reproductive Health Research Unit Witwatersrand University, Johannesburg, South Africa;

- Institute for Health Economics at the University of Dhaka in Bangladesh; and

- University of Costa Rica in San José.

FRONTIERS has also given workshops and seminars for non-governmental organizations, Ministries of Health, and technical assistance organizations. Between June 1999 and December 2001, FRONTIERS provided 19 courses, workshops, meetings, and orientations serving approximately 400 participants from over 40 countries (see Table 1). 


\section{Table 1. FRONTIERS Capacity Building Courses, June 1999 - December 2001}

\begin{tabular}{|c|c|c|c|c|}
\hline Topic/Agency/Site & Dates & Participants & Countries & Outputs \\
\hline $\begin{array}{l}\text { Operations } \\
\text { Research } \\
\text { Save the Children } \\
\text { Washington, DC }\end{array}$ & $6 / 1999$ & $\begin{array}{l}28 \text { STC staff } \\
\text { (managers and } \\
\text { researchers) }\end{array}$ & $\begin{array}{l}10 \text { US-based and } 18 \text { field } \\
\text { staff }\end{array}$ & OR proposals \\
\hline $\begin{array}{l}\text { Operations } \\
\text { Research } \\
\text { Cairo Demographic } \\
\text { Center (CDC), Cairo, } \\
\text { Egypt }\end{array}$ & $7 / 1999$ & $\begin{array}{l}20 \text { junior- to mid- } \\
\text { level population } \\
\text { program } \\
\text { researchers and } \\
\text { managers }\end{array}$ & $\begin{array}{l}\text { Armenia, Bangladesh, } \\
\text { Egypt, Gambia, } \\
\text { Indonesia, Kenya, } \\
\text { Liberia, Nigeria, } \\
\text { Palestine, Romania, } \\
\text { South Africa, Zambia } \\
\end{array}$ & OR Proposals \\
\hline $\begin{array}{l}\text { Operations } \\
\text { Research } \\
\text { PROCOSI } \\
\text { La Paz, Bolivia }\end{array}$ & $7 / 1999$ & $\begin{array}{l}30 \text { project } \\
\text { coordinators } \\
\text { (managers and } \\
\text { researchers) from } \\
21 \text { organizations } \\
\end{array}$ & Bolivia & OR Proposals \\
\hline $\begin{array}{l}\text { Operations } \\
\text { Research } \\
\text { RHRU } \\
\text { Witwatersrand U. } \\
\text { Johannesburg, SA }\end{array}$ & $7 / 1999$ & $\begin{array}{l}25 \text { evaluation and } \\
\text { research officers } \\
\text { and project } \\
\text { managers }\end{array}$ & $\begin{array}{l}\text { Botswana, Ethiopia, } \\
\text { Ghana, Kenya, Malawi, } \\
\text { Nigeria, Rwanda, South } \\
\text { Africa, Tanzania, } \\
\text { Uganda, Zambia, } \\
\text { Zimbabwe }\end{array}$ & OR Proposals \\
\hline $\begin{array}{l}\text { Budgeting and } \\
\text { Economic Evaluation } \\
\text { Makerere U/MOH, } \\
\text { Kampala, Uganda }\end{array}$ & 9/1999 & $\begin{array}{l}20 \mathrm{MOH} \text { and donor } \\
\text { agency staff from } \\
10 \text { countries } \\
\text { (managers) }\end{array}$ & $\begin{array}{l}\text { Eritrea, Ethiopia, Kenya, } \\
\text { Malawi, Rwanda, } \\
\text { Somalia, Tanzania, } \\
\text { Uganda, Zambia, } \\
\text { Zimbabwe }\end{array}$ & $\begin{array}{l}\text { Cost and } \\
\text { budgeting } \\
\text { exercises }\end{array}$ \\
\hline $\begin{array}{l}\text { Economic Evaluation } \\
\text { FRONTIERS Staff } \\
\text { Chapel Hill, North } \\
\text { Carolina }\end{array}$ & $11 / 1999$ & $\begin{array}{l}\text { 17 FRONTIERS, } \\
\text { USAID and CA } \\
\text { staff (researchers } \\
\text { and managers) }\end{array}$ & $\begin{array}{l}\text { International and US- } \\
\text { based staff of USAID and } \\
\text { CAs }\end{array}$ & Cost exercises \\
\hline $\begin{array}{l}\text { Operations } \\
\text { Research } \\
\text { MOH/PRIME } \\
\text { San Salvador, EI } \\
\text { Salvador }\end{array}$ & $3 / 2000$ & $20 \mathrm{MOH}$ managers & El Salvador & OR Proposals \\
\hline $\begin{array}{l}\text { Willingness to Pay } \\
\text { Master's Program in } \\
\text { RH Evaluation, U. } \\
\text { Costa Rica, San } \\
\text { Jose, Costa Rica }\end{array}$ & $4 / 2000$ & $\begin{array}{l}6 \text { MA students } \\
\text { enrolled in } \mathrm{RH} \\
\text { evaluation program }\end{array}$ & $\begin{array}{l}\text { Costa Rica, El Salvador, } \\
\text { Guatemala, Honduras }\end{array}$ & $\begin{array}{l}\text { Research } \\
\text { Reports }\end{array}$ \\
\hline $\begin{array}{l}\text { Experimental Design } \\
\text { Master's Program in } \\
\text { RH Evaluation, U. } \\
\text { Costa Rica, San } \\
\text { Jose Costa Rica }\end{array}$ & $5 / 2000$ & $\begin{array}{l}9 \text { MA students } \\
\text { enrolled in } \mathrm{RH} \\
\text { evaluation program }\end{array}$ & $\begin{array}{l}\text { Bolivia, Costa Rica, El } \\
\text { Salvador, Guatemala, } \\
\text { Honduras }\end{array}$ & $\begin{array}{l}\text { Preparation of } \\
\text { experimental } \\
\text { designs }\end{array}$ \\
\hline $\begin{array}{l}\text { Operations } \\
\text { Research } \\
\text { RHRU } \\
\text { Witwatersrand U. } \\
\text { Johannesburg, SA }\end{array}$ & $7 / 2000$ & $\begin{array}{l}31 \text { evaluation and } \\
\text { research officers } \\
\text { and project } \\
\text { managers }\end{array}$ & $\begin{array}{l}\text { Botswana, Ethiopia, } \\
\text { Kenya, Lesotho, Malawi, } \\
\text { Nigeria, Rwanda, South } \\
\text { Africa, Tanzania, } \\
\text { Uganda, Zambia, } \\
\text { Zimbabwe }\end{array}$ & OR Proposals \\
\hline
\end{tabular}




\begin{tabular}{|c|c|c|c|c|}
\hline $\begin{array}{l}\text { Operations } \\
\text { Research } \\
\text { CDC, Cairo, Egypt }\end{array}$ & $8 / 2000$ & $\begin{array}{l}22 \text { junior- to mid- } \\
\text { level population } \\
\text { program } \\
\text { researchers and } \\
\text { managers }\end{array}$ & $\begin{array}{l}\text { Bangladesh, China, } \\
\text { Egypt, Gambia, Ghana, } \\
\text { Liberia, Nigeria, } \\
\text { Palestine, Philippines, } \\
\text { Sudan, Yemen }\end{array}$ & OR Proposals \\
\hline $\begin{array}{l}\text { Operations } \\
\text { Research } \\
\text { Orientation } \\
\text { Reproductive Health } \\
\text { Alliance Europe, } \\
\text { London, UK }\end{array}$ & $11 / 2000$ & $\begin{array}{l}13 \text { representatives } \\
\text { of UK-based } \\
\text { international RH } \\
\text { organizations } \\
\text { (managers and } \\
\text { researchers) }\end{array}$ & $\begin{array}{l}\text { UK agencies: IPPF, Marie } \\
\text { Stopes, JSI-UK, } \\
\text { Population Concern, } \\
\text { London School of } \\
\text { Tropical Medicine and } \\
\text { Hygiene, Leeds U., } \\
\text { Southampton U. }\end{array}$ & $\begin{array}{l}\text { Plan for follow- } \\
\text { up meetings }\end{array}$ \\
\hline $\begin{array}{l}\text { Operations } \\
\text { Research } \\
\text { Institute of Health } \\
\text { Economics, Univ. of } \\
\text { Dhaka, Dhaka, } \\
\text { Bangladesh }\end{array}$ & $1 / 2001$ & $\begin{array}{l}22 \text { representatives } \\
\text { of } \mathrm{RH} \text { government } \\
\text { and } \mathrm{NGO} \text { agencies }\end{array}$ & $\begin{array}{l}\text { Bangladesh, Benin, } \\
\text { China, India, Ivory Coast, } \\
\text { Malaysia, Nepal, Pakistan }\end{array}$ & OR Proposals \\
\hline $\begin{array}{l}\text { OR Workshop } \\
\text { WHO } \\
\text { Bucharest, Romania }\end{array}$ & $3 / 2001$ & $\begin{array}{l}11 \text { WHO } \\
\text { Collaborating } \\
\text { Centre Directors } \\
\text { and UNFPA staff } \\
\text { (researchers and } \\
\text { managers) }\end{array}$ & $\begin{array}{l}\text { Czech Republic, } \\
\text { Kazakhstan, Latvia, } \\
\text { Lithuania, Romania, } \\
\text { Russia }\end{array}$ & $\begin{array}{l}\text { OR course } \\
\text { designed }\end{array}$ \\
\hline $\begin{array}{l}\text { OR Seminar } \\
\text { U. of Edinburgh } \\
\text { Edinburgh, UK }\end{array}$ & $6 / 2001$ & 12 MSc. Students & $\begin{array}{l}\text { Bangladesh, China, } \\
\text { Ethiopia, Georgia, Nepal, } \\
\text { Nigeria, Turkey }\end{array}$ & $\begin{array}{l}\text { OR defined at } \\
\text { one-day } \\
\text { seminar }\end{array}$ \\
\hline $\begin{array}{l}\text { OR Workshop } \\
\text { Reproductive Health } \\
\text { Alliance, Europe } \\
\text { London, UK }\end{array}$ & $6 / 2001$ & $\begin{array}{l}18 \text { participants from } \\
\text { UK-based } \\
\text { reproductive health } \\
\text { organizations } \\
\text { (managers and } \\
\text { researchers) }\end{array}$ & $\begin{array}{l}\text { UK agencies: IPPF, Marie } \\
\text { Stopes, JSI-UK, JSI-UK, } \\
\text { Institute for Health Sector } \\
\text { Development, London } \\
\text { School of Tropical } \\
\text { Medicine and Hygiene, } \\
\text { Leeds U., } \\
\text { Southampton U. }\end{array}$ & OR Proposals \\
\hline $\begin{array}{l}\text { Willingness to Pay } \\
\text { Survey Workshop } \\
\text { The Futures Group } \\
\text { International, } \\
\text { Washington D.C. }\end{array}$ & $6 / 2001$ & $\begin{array}{l}14 \text { researchers } \\
\text { from Washington } \\
\text { D.C. CAs }\end{array}$ & $\begin{array}{l}\text { AED, CMS, DKT, IPPF, } \\
\text { JHPIEGO, TFGI }\end{array}$ & $\begin{array}{l}\text { WTP } \\
\text { questionnaires } \\
\text { designed and } \\
\text { demand curves } \\
\text { estimated }\end{array}$ \\
\hline $\begin{array}{l}\text { OR Workshop } \\
\text { WHO and Eastern } \\
\text { European Institute } \\
\text { for Reproductive } \\
\text { Health, Targu } \\
\text { Mures, Romania }\end{array}$ & $10 / 2001$ & $\begin{array}{l}17 \text { researchers and } \\
\text { program managers } \\
\text { from seven Eastern } \\
\text { Europe Health } \\
\text { Ministries and } \\
\text { NGOs }\end{array}$ & $\begin{array}{l}\text { Czech Republic, } \\
\text { Kazakhstan, Latvia, } \\
\text { Lithuania, Moldova, } \\
\text { Romania, Russia, } \\
\text { Ukraine }\end{array}$ & OR Proposals \\
\hline $\begin{array}{l}\text { Reproductive Health } \\
\text { OR Capacity } \\
\text { Building } \\
\text { Consultation } \\
\text { WHO, USAID } \\
\text { Geneva, Switzerland }\end{array}$ & $12 / 2001$ & $\begin{array}{l}\text { Approximately } 75 \\
\text { participants from } \\
\text { WHO, UNFPA, } \\
\text { FRONTIERS, } \\
\text { USAID, other } \\
\text { international donors } \\
\text { and OR training } \\
\text { centers }\end{array}$ & $\begin{array}{l}\text { Europe, North and South } \\
\text { America, Africa, Asia and } \\
\text { Pacific }\end{array}$ & Report \\
\hline
\end{tabular}




\section{Building Capacity for OR Research in Africa}

The capacity building strategy for a specific institution is based on an evaluation of the needs of the region. For example, the following section presents an analysis of the problems that OR capacity building efforts in sub-Saharan Africa must address. Many of the problems encountered in Africa are also common to Latin America and Asia.

FRONTIERS' capacity-building work in Africa targets major weaknesses that limit reproductive health research as well as research on other health and social science topics, including:

- Research agendas. Local funding for research is highly constrained. Most research in the region is initiated, funded, and conducted by non-African organizations with weak local involvement. Research agendas tend to reflect the priorities of donors rather than a critical analysis of national needs and resources.

- Skills in applied reproductive health research. The pool of African researchers with training in applied reproductive health research is small. Few Africans holding $\mathrm{PhDs}$ work in reproductive health, and even fewer are based in the region.

Reproductive health research therefore tends to be carried out by master's-level researchers and professionals from other disciplines.

- Use of research in decisionmaking. Most African institutions lack a tradition of evidence-based decisionmaking, either by program managers or policymakers. Few decisionmakers have the skills or experience they need to incorporate research into program planning, monitoring, or evaluation.

FRONTIERS staff have identified four strategies to improve OR capabilities and utilization of research findings:

1. Building local capacity. FRONTIERS seeks to improve the skills of African researchers by:

- Supporting short courses on OR in reproductive health;

- Providing fellowships to allow mid-level researchers to increase their experience in reproductive health $\mathrm{OR}$;

- Mentoring researchers in African organizations working with FRONTIERS OR projects; and

- Recruiting African staff for FRONTIERS offices and projects.

2. Strengthening African-led research efforts. To increase the capacity of African organizations to identify OR priorities, FRONTIERS supports regional policy and research networks and works with national policymaking bodies to increase the use of research findings.

3. Enhancing the relevance of research for managers and decisionmakers. FRONTIERS has developed procedures for maximizing research utilization:

- Working with managers, policymakers and donors, rather than researchers only, to determine program information needs; 
- Developing research studies with the participation of managers and policymakers to increase program relevance; and

- Working with decisionmakers to interpret the programmatic implications of the findings and to translate recommendations into action.

4. Increasing the capacity of program managers to use research. In addition to providing post-research technical assistance to help programs use study results in decisionmaking, FRONTIERS supports short-term training for managers to use research and empirical evidence. Short courses include an overview of operations research, OR on specific issues such as quality of care, and economic evaluation.

FRONTIERS will continue to focus primarily on improving the capacity of managers to use research results and will also provide some support to improve the skills of researchers undertaking OR. To further these goals the Program is exploring collaboration with organizations such as World Health Organization, European donors and technical assistance agencies, and USAID Cooperating Agencies working in Africa.

\section{Institutionalizing OR at the Cairo Demographic Center}

FRONTIERS' work with the Cairo Demographic Center (CDC) illustrates the capacity building process in a single organization. Established as a training and research center in 1963 with sponsorship from the Egyptian government (GOE) and the United Nations, the CDC is a natural site for the institutionalization of OR. The CDC offers bachelor's, master's, and doctoral diplomas in demography and in population and development. Beginning in the mid-1990s it began to modernize its curriculum to include topics such as sustainable development, reproductive health, and gender.

In 1999 and 2000, 41 students from 19 countries participated in the two OR courses held at CDC. Center faculty, along with FRONTIERS staff and consultants, taught the courses, with CDC participation in course planning and teaching increasing greatly during the second course.

In 2001 the CDC added 40 hours of OR training to its undergraduate curriculum. The first module was taught to students seeking a General Diploma -- a basic certificate that allows entry-level professionals to work in statistical institutes or health and population agencies. In 2002, the OR module will also be offered for students seeking a Special Diploma, which provides more advanced demographic training and exposes students to such issues as population and environment, reproductive health, and gender. Both 
diploma programs are supported by the GOE and the United Nations Population Fund; about a third of the students in the programs come from outside of Egypt.

CDC also included lectures on OR during a recent one-month course on quality of care in reproductive health, co-sponsored by the CDC and a Rockefeller Foundation program, Partners in Population and Development (South to South collaboration).

\section{Cairo Demographic Center Operations Research Institutionalization Strategies}

- FRONTIERS staff initiated conversations with the CDC Director concerning introduction of OR into the CDC curriculum early in the collaboration and continued these discussions throughout the institutionalization effort.

- CDC faculty members were responsible for course implementation and were involved in teaching duties.

- FRONTIERS made an informal, long-term commitment to support OR at CDC.

- FRONTIERS staff participated in curriculum development meetings with CDC staff in designing the OR contents to be included in diploma courses.

- CDC faculty and other local resource persons assumed increasing responsibility.

- Copies of all course presentations, handouts, and practice datasets were archived at $\mathrm{CDC}$ for future use.

- Copies of all materials were donated to the CDC library. A large supply of OR textbooks was also donated for use in subsequent courses.

\section{Capacity Building in Financial Management and Economic Evaluation}

Sustainability and cost-effectiveness are emerging as crucial issues for managers in reproductive health. FRONTIERS' capacity building emphasizes the development of local skills in these important areas. FRONTIERS' partner, Family Health International, provides courses and modules to enhance program managers' capacity to collect, analyze, and interpret data relevant to the financial sustainability of their programs. The courses give participants an understanding of economic issues and provide hands-on experience working with simplified data from OR studies.

The major courses and modules on financial management and economic evaluation are:

- Financial Management of Health Services. This course describes budget elements and mechanics and teaches students to prepare and monitor budget performance. At the end of the course, participants can read and understand a budget, prepare activity and program budgets, and use budgets as management tools. 
- Costing of Reproductive Health Services. This course describes types of program costs and the relationship between costs and the production process. It teaches students to estimate the costs of individual services, programs, and service expansion. Lectures are complemented by in-class exercises that require participants to estimate total program and individual service costs.

- Pricing and Revenue Analysis. This module covers the relationships between price and service volume and the use of willingness-to-pay surveys to estimate demand for services. Often the course participants understand the principles behind demand curves and can design and interpret the results of a willingness-topay study.

- Economic Evaluation. This module focuses on estimating the costs associated with various alternatives for service expansion. By the course's end, students can distinguish among and interpret the results of different types of evaluations.

\section{Collaboration and Technical Assistance to Increase OR Use}

To be sustainable, operations research must be valued and used by organizations throughout the development community. Consequently, FRONTIERS provides technical assistance to other donors wishing to develop their own OR programs. These organizations recognize the need for OR in their programs but lack the experience to design OR training and research strategies. FRONTIERS has conducted orientations for several United Kingdom-based institutions and USAID Cooperating Agencies. It has also conducted workshops on OR proposal development for 21 nongovernmental organizations in Bolivia and for 20 managers of the Ministry of Health in El Salvador.

The most notable collaboration has been with the World Health Organization (WHO). FRONTIERS is helping WHO add OR to its clinical and social science reproductive health research programs. Technical assistance to WHO is part of a Memo of Understanding (MOU) that includes WHO, USAID, and the Population Council. Collaborative activities have included:

- In March 2001, as part of the MOU, FRONTIERS and WHO held a meeting in Bucharest, Romania to organize a program of OR training and research in Eastern Europe and Eurasia during the period 2001 - 2003. Representatives from WHO collaborating centers in the Czech Republic, Kazakhstan, Latvia, Lithuania, Romania, and Russia attended. Participants stressed the need for OR to help their reproductive health care programs make the transition from the state model of health care to the newly emerging system, a mixture of state and free market medicine. WHO and FRONTIERS sponsored the region's first OR training course in October 2001 in Targu Mures, Romania. WHO, FRONTIERS and the Eastern European Institute for Reproductive Health provided facilitators for the course.

- In December 2001, WHO, USAID, and FRONTIERS hosted an International Consultation in Geneva, Switzerland. The Consultation brought together donor and technical cooperation agencies interested in promoting the use of OR in reproductive health and centers in developing countries that currently provide OR training. Participants explored interagency cooperation in building OR capacity in 
developing countries and looked at ways to stimulate increased training and research opportunities in OR for developing country researchers and managers.

- WHO and FRONTIERS have also been working together to design operations research courses for Francophone Africa and Latin America. WHO sponsored two representatives to attend a FRONTIERS sponsored OR course held at the University of Dhaka. The representatives reported that there was a need to replicate the course in a Francophone setting and asked for FRONTIERS'

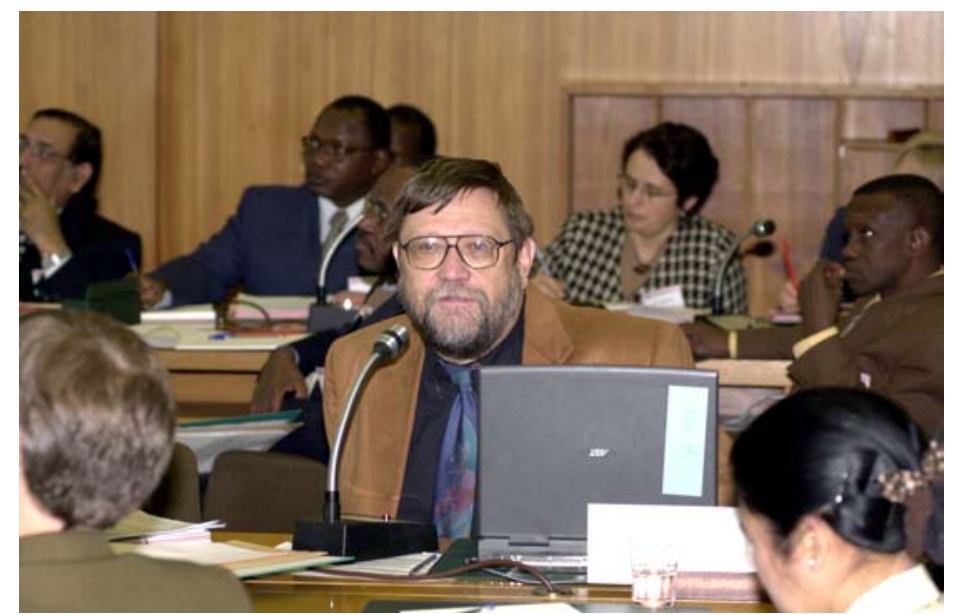
assistance in developing the curriculum and providing instructors for the course.

- In Latin America, WHO and FRONTIERS are working with the School of Public Health, University of Costa Rica, to offer a course in research utilization in 2002. As in Romania, FRONTIERS will provide assistance in curriculum development and teaching. The university began introducing OR topics to its Master's degree program in Population and Health in 1999 with FRONTIERS support.

\section{Fellowship Program}

A Fellowship Program is the third element in the FRONTIERS capacity building program. To increase the cadre of professionals with OR skills in developing countries, FRONTIERS supports a fellowship program for persons with graduate training who are interested in reproductive health OR as a career. The fellowship helps increase the research skills of the fellows and provide them with practical experience that will enable them to design, monitor and analyze OR projects. An important part of the experience is learning to identify program problems that need solving and learning to work with program managers.

The fellowship program is inspired by the successful experiences of the regional OR projects in Africa, Asia, and Latin America during the 1990s. A very high proportion of the international fellows from the University of Michigan's Population Fellows Program and locally recruited fellows have gone on to careers in reproductive health programs and operations research.

Fellows receive a stipend and learn by working on OR projects under the supervision and mentoring of FRONTIERS staff members for 1-2 years. All are residents of the country or region in which they work. Currently, FRONTIERS supports five fellows in Bolivia, Egypt, Guatemala, the Philippines and Uganda. An additional fellow is being recruited in South Africa. 
In a typical fellowship experience, the fellow works on one or more ongoing OR projects. The fellow usually assumes responsibility for supervision of data collection, data editing and analysis, and report writing. In a two-year fellowship, the fellow usually has the opportunity to identify and design an OR project and present the results at an international meeting. Some fellowships also include the opportunity to take courses in subjects such as statistics and English. If the fellow has limited program experience, he/she may do a study tour of service delivery organizations and facilities.

\section{Conclusion}

FRONTIERS seeks to institutionalize capacity building by: (1) increasing the number of service delivery organizations that use OR and (2) increasing the number of research organizations capable of conducting and teaching OR. Investment in capacity building will ensure that operations research will make a continuing, significant contribution to reproductive health and family planning programs and policies. 


\section{Z Frontiers}

\section{Frontiers in Reproductive Health}

Population Council

4301 Connecticut Ave. N.W.

Suite 280

Washington, D.C. 20008

U.S.A.

Tel.: 202-237-9400

Fax: 202-237-8410

E-mail: frontiers@pcdc.org

Website: www.popcouncil.org

\section{Africa}

Population Council Regional Office

P.O. Box 17643

Nairobi

Kenya

Tel.: 254-2-713480/1/2/3

Fax: 254-2-713479

E-mail: publications@popcouncil.or.ke

\section{Asia and the Near East}

Population Council Regional Office

Ground Floor, Zone 5A

India Habitat Center

Lodi Road

New Delhi 110003

India

Tel.: 91-11-461-0913

Fax: 91-11-464-2903

E-mail: frontiers@pcindia.org

\section{Latin America and the Caribbean}

Population Council Regional Office

Escondida 110

Villa Coyoacán

04000 Mexico, D.F.

Mexico

Tel.: 52-5-659-8537

Fax: 52-5-554-1226

E-mail: disemina@popcouncil.org.mx

\section{Population Council}

The Population Council is an international, nonprofit, nongovernmental institution that seeks to improve the well-being and reproductive health of current and future generations around the world and to help achieve a humane, equitable, and sustainable balance between people and resources. The Council conducts biomedical, social science, and public health research and helps build research capacities in developing countries. Established in 1952, the Council is governed by an international board of trustees. Its New York headquarters supports a global network of regional and country offices. 